\author{
テラヘルツ波コンピュータ断層撮影法 \\ 今村 元規，西名 繁樹 \\ (株)アドバンテスト 新企画商品開発室 (テ989-3124 宮城県仙台市青葉区上愛子字松原48-2アドバンテスト研究所内)
}

\title{
Terahertz Wave Computed Tomography
}

\author{
Motoki IMAMURA and Shigeki NISHINA \\ ADVANTEST Corporation, New Concept Product Initiative, 48-2 Matsubara, Kamiayashi, Aoba-ku, Sendai, Miyagi 989-3124
}

(Received March 9, 2012)

\begin{abstract}
Characterization of the interaction path of terahertz $(\mathrm{THz})$ waves transmitted through a specific material can be applied to non-destructive imaging and testing. The Advantest TAS7000 3D imaging system employs non-destructive imaging technology using computed tomography (CT). This system performs analysis and imaging in both two and three dimensions; enabling identification of specific individual materials in a target sample. One important and unique feature of this technology is the non-destructive nature of terahertz spectrum analysis, (non-ionic) thus differing from traditional X-ray CT.
\end{abstract}

Key Words: Terahertz, Computed tomography, 3D imaging, Non-destructive analysis

1. はじめに

赤外線とミリ波帯の間の周波数帯に位置するテラヘル ツ $(\mathrm{THz})$ 波の特徴は, 吸収スペクトル (また, 指紋スぺ クトルと呼ばれる)が得られ，視覚的に不透明な材料を 貫通することが挙げられる。川瀬らは，このTHz波の特 徵を用いて, 2次元 $(2 \mathrm{D})$ 分光イメージングにより封筒に 隠された違法薬物の同定を行うことで，THz波による非 破壊解析の高い有用性を示した ${ }^{1)}$. THz計測の空間分解 能は，実用的なイメージングに適していることから，材 料, バイオテクノロジー, セキュリティなどの分野での 発展が期待されている22.

一方, 現在の非破壊解析技術で代表的なものは, $\mathrm{THz}$ 波と同じく電磁波であるX線を用いたものであり，X線 を使用したコンピュータ断層撮影法 $(\mathrm{CT})$ は, 医療診断 のための非破壊断層検査法として1972年にHounsfieldら により開発された。CT法とは測定で得た投影データか ら逆ラドン変換を行って再構成した断面像を得る解析法 である ${ }^{3,4)}$. 創成期のX線CTについては, Beckmannの記 事5)が詳しい

THz波を用いたCT測定は, Quantum Cascade Laser (QCL) を使用した報告 ${ }^{6}$ や, Ferguson らによる時間領域 分光法(Time Domain Spectroscopy, 以下TDS法と略記) による報告 ${ }^{7)}$ がある. TDS法による THz波CT (以下 $\mathrm{THz}$ CT) は, 分光情報から成分濃度の分布解析が可能 ${ }^{8}$ であ り，これは，一般に分光情報を使用しないX線CTに対す る, THz CTの特徴の一つである。
$\mathrm{THz}$ CTによる非破壊解析が特に有効な対象としては, 自動車用セラミック部品が挙げられ，触媒コーティング 濃度や内部に堆積するスス濃度を3D分布解析すること が可能であり, 部品品質向上やエンジン制御の改善ツー ルとして有用である ${ }^{9)}$.

我々は, この新しい非破壊解析技術を実用化した 「TAS7000 3Dイメージング解析システム」(Fig. 1)を既に 製品化している。本稿では，世界最初のTHz CTの商用 機であるTAS7000の技術の概要, 特にイメージングのた めの高速測定技術とレーザー制御技術について述べる. また, TAS7000の測定例について紹介し，THz CTによ る非破壊解析への応用について解説する。

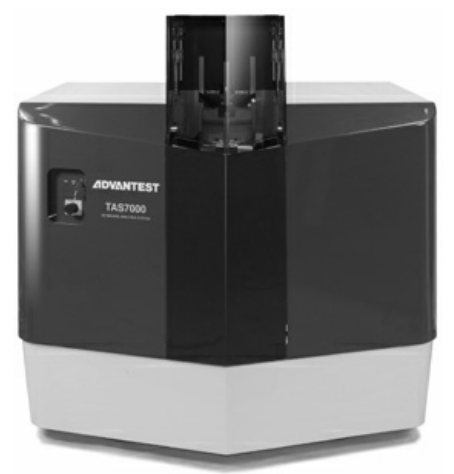

Fig. 1 TAS7000 3D Imaging Analysis System. 


\section{2. $\mathrm{THz}$ 波CTの技術}

\subsection{TAS7000の概要}

THz CTは, 測定対象物の内部形状 - 特性を非破壊の まま2次元 $\cdot 3$ 次元画像として可視化・解析し, 結果を立 体的に表示可能である，構造変化はもちろんのこと，分 光情報を使うことでその成分の特定や物質量まで解析す ることができる。以下に，TAS7000の主な仕様を示す。

\section{主な仕様 ${ }^{\dagger}$ :}

- 解析項目

2D/3D CT濃度分布解析 及び, $\mathrm{THz}$ 波の透過分光特 性測定

- 解析周波数

高ダイナミック・レンジ・モジュール：0.02 THz〜 $0.6 \mathrm{THz}$

広帯域モジュール：0.05 THz〜 $3 \mathrm{THz}$

- CT測定空間分解能

$\leqq 3 \mathrm{~mm}($ ワイヤーファントムにて， MTF 10\%)

ロスループット

最高波形取得レート：250 Hz(分光測定モード)

CT断面像取得時間： 15 分 (CT像1断面測定)

ロ試料サイズ/試料質量

$\leqq \Phi 310 \mathrm{~mm}(12.2$ inch $) \times \mathrm{H} 310 \mathrm{~mm}(12.2$ inch $), \leqq 20 \mathrm{~kg}$

TAS7000の構成を示したブロック図をFig. 2に示す. 基本的な分光原理はTDS法 ${ }^{10,11)}$ であり, 超短光パルス ファイバレーザーをTHz波発生・検出器であるPhoto Conductive Switch (PCS) にそれぞれ照射して, THz領域 の時間波形をサンプリングにて取得する。発生したパル スはTHz帯までのブロードなスペクトル成分を含んでお り，被測定物を透過したTHz波形を高速フーリエ変換 (FFT)することで被測定物の透過特性 (スペクトル)が得 られる。このデー夕には，振幅だけでなく位相情報も同 時に含まれるので，材料の複素屈折率なども求められ る.

さらに, 被測定物を空間的にスキャンして, CT法に
より再構成した断面像を得ることができる，本装置で使 用される超短光パルスファイバレーザー, 光サンプリン グ，CT法の技術について，以降にそれぞれ詳しく述べ る.

\section{$2.2 \mathrm{THz}$ 光サンプリング法による高速分光測定}

CT法によるイメージングには，多くの測定データが 必要であり，測定の高速化が実用化の課題となる。

従来のTDS法によるTHzパルスの時間波形取得は，卜 ランスレーションステージによる機械的な光遅延量の変 化により得られていた。しかし，この方法は1波形を測 定するのに拈よそ数分間かかるため，これをCT測定に 適用すると，物体の3D内部画像を得るのに数日の測定 時間を必要とする計算になる。

そこで我々は，高スループットの波形測定を機械的光 遅延方式によらず, 電気的な制御で行う光サンプリング オシロスコープの原理を用いた。 これは，2台のフェム ト秒パルスレーザーの繰返し周波数に僅かな差 $\Delta f$ 与え ることで，その逆数 $1 / \Delta f$ の時間間隔で波形取得が可能な 光サンプリング法 ${ }^{1213)} \mathrm{THz}$ パルスの波形測定に応用 ${ }^{14)}$ する $\mathrm{THz}$ 光サンプリング法である。従来のTHz光サンプ リング法では，2台のパルスレーザー間のタイミングの ズレにより測定ジッタが発生していたが，我々は，新た にその要因を改善するジッ夕低減回路を搭載すること で，高スループットでかつ広帯域測定を実現した。Fig. 3 に本機のサンプリングの原理 ${ }^{15)}$ と Table 1にその特徴を それぞれ示す。

Table 1 Features of THz optical sampling method.

\begin{tabular}{ccc}
\hline & Conventional technology & TAS7000 \\
\hline Method & $\begin{array}{c}\text { Terahertz TDS } \\
\text { (Time-Domain Spectroscopy) }\end{array}$ & Terahertz optical sampling \\
\hline Time sweep & Mechanical optical delay & Electrical control sweep \\
\hline Light source & Branches by one light source & Two light sources \\
\hline Throughput & 1 minute/sweep & $\begin{array}{c}\text { Min. } 4 \mathrm{~ms} / \mathrm{sweep} \\
15 \text { minute/image }\end{array}$ \\
\hline $\begin{array}{c}\text { Influence by jitta } \\
\text { of light source }\end{array}$ & Not Affect & $\begin{array}{c}\text { Affect } \rightarrow \text { We overcame } \\
\text { with the method of low jitta } \\
\text { light source }\end{array}$ \\
\hline
\end{tabular}

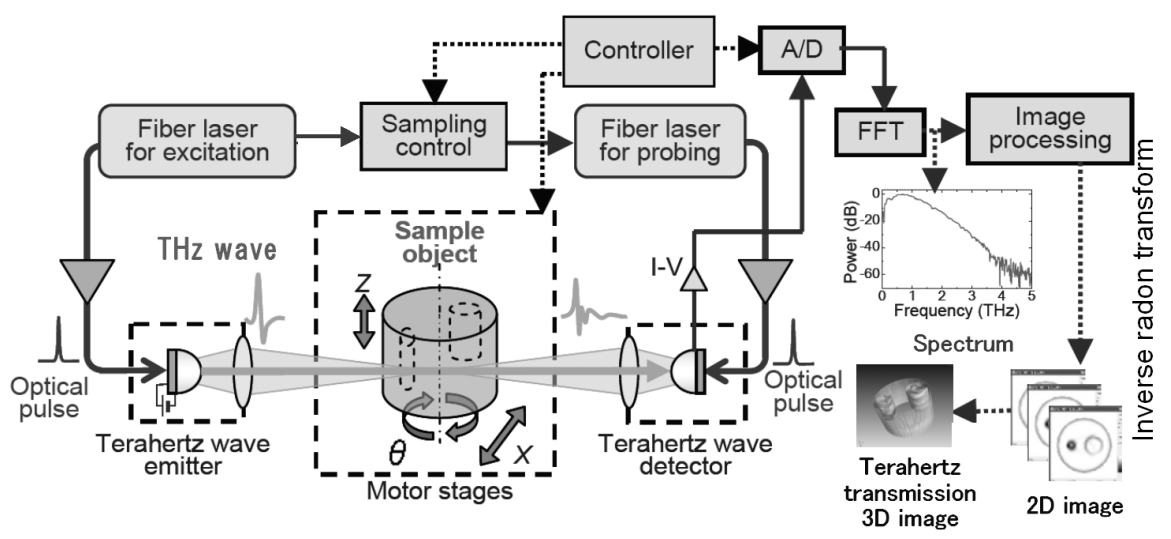

Fig. 2 Schematic diagram of TAS7000 3D imaging analysis system.

\footnotetext{
${ }^{\dagger}$ URL: http://www.advantest.co.jp/products/3DIAS/index.shtml
} 


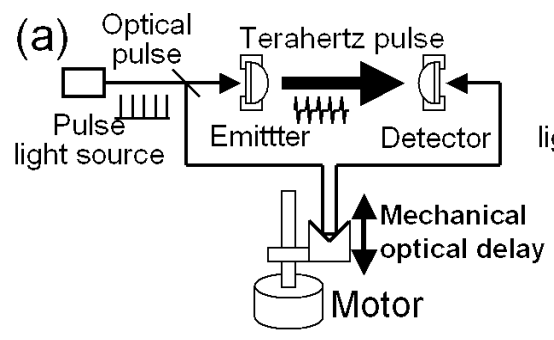

Fig. 3 Methods of THz spectroscopy:

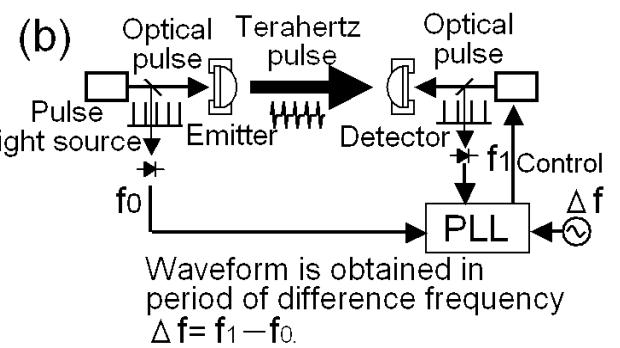

: (a) THz TDS (b) THz optical sampling.

本方式により，1秒間に最大 250 回のTHz波パルス波形 が取得可能となり, CT法による断面像取得時間は15分 以内, サンプル全体での $3 \mathrm{D}$ 像の取得も5 時間以内に短縮 され，THzCT装置の実用化が可能になった。

\section{3 高出力超短パルスファイバレーザー技術}

THz波の時間波形を測定するには, 測定対象のTHz波 のパルス幅が約 $300 \mathrm{fs}$ と非常に短く，パルス幅以下の時 間の不確かさでの測定が求められる. 光サンプリングに おいては，その不確かさの要因となる2つのファイバ レーザー間の位相関係の変動 (ジッ夕)を極めて低く抑え た低位相ノイズのパルス発振を行うレーザーの制御が必 要であり, それには共振器長を制御して, 発振周波数を 外部信号にPLLで同期させることが有効である ${ }^{16)}$.

そこで，本装置に用いられている低位相ノイズの超短 パルスファイバレーザー技術について説明する (Fig. 4).

光源として用いられているのは, 半導体可飽和吸収ミ ラー (SESAM: Semiconductor Saturable Absorber Mirror)を

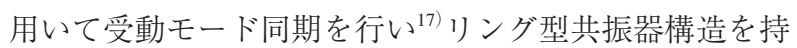

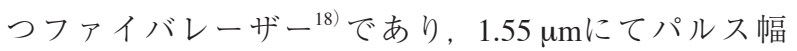
$80 \mathrm{fs}$ 以下, 平均パワー $200 \mathrm{~mW}$, 繰返し周波数 $50 \mathrm{MHz}$ の セルフスタートな発振が得られている。ファイバレー ザーからの出力は, 分岐カプラによって一部を取り出 し, 共振器長を変化させる制御で繰返し周波数の安定化 を行った。

Fig. 5に本ファイバレーザーの位相雑音スペクトルを 示す。共振器長のPLL制御により, 低域の位相雑音が抑 制されていることがわかる。この位相雑音スペクトルを 積分することで算出されるRMSジッタは，(a)のフリー
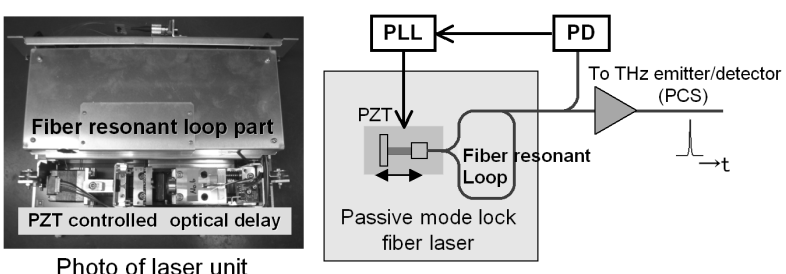

Fig. 4 Passive mode-lock fiber laser.

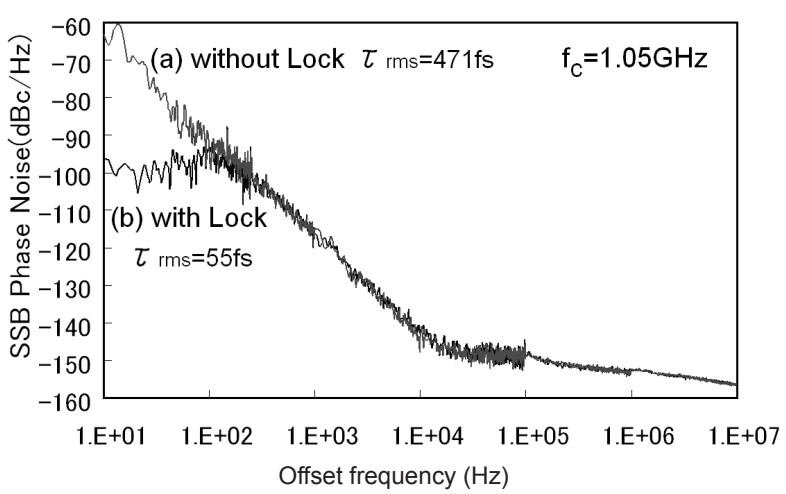

Fig. 5 Phase noise spectrum.

ランニング471 fsに対して(b) のPLL制御時は55fsであ り，位相ノイズ(ジッタ)が十分小さく抑えられている.

THz光サンプリング方式においては，本手法を用い， $\mathrm{THz}$ パルス発生側の光源の発振位相を規準として，検出 側光源の位相関係を一定の周波数差となるように制御を 行い, ジッタの影響を排除している.

次に, THz光サンプリング法を用いて測定したTHzパ ルスの時間波形測定例とそのFFTによるパワースペクト ルをFig. 6にそれぞれ示す。この結果から，4 THz超にわ (a)

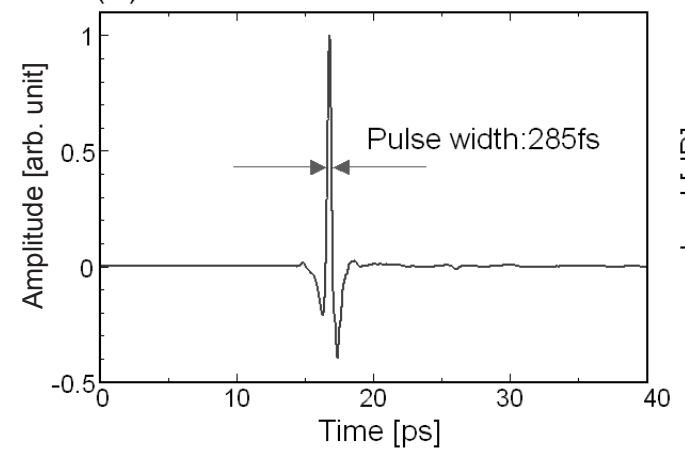

(b)

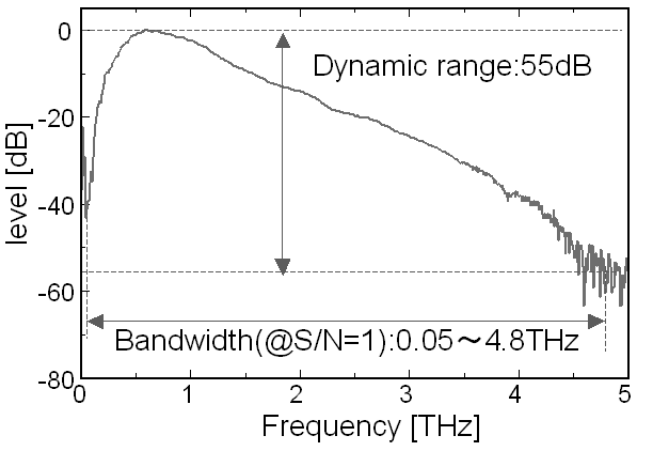

Fig. 6 (a) THz waveform of sampled signal (b) FFT power spectrum. 
たり広帯域なTHz波スペクトルが観測できていることが わかる。

\subsection{CT法の原理}

CT法は物体の内部特性を知るためのイメージング法 として優れた方式である。内部が未知の物体に対し, 様々な方向から $\mathrm{THz}$ 波を照射して，透過する $\mathrm{THz}$ 波を Fig. 7のように投影データとして測定する。 その值に対 し，以下に示す逆投影演算処理を行うことで，物体の断

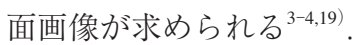

THz波が伝搬する際には, 媒質の吸収により減衰が生 じる。そその伝搬の単位長当たりの減衰率 $[\mathrm{dB}]$ が空間分 布 $f(x, y)$ を持つ物体に電磁波を透過させる。すると, そ の電磁波の減衰量の投影デー夕は, 以下の様に表され る.

$$
\begin{aligned}
p(r, \theta) & =\int_{-\infty}^{+\infty} f(x, y) d s \\
& =\int_{-\infty}^{+\infty} f(r \cos \theta-s \sin \theta, r \sin \theta+s \cos \theta) d s
\end{aligned}
$$

これをラドン変換という.

ここで, $f(x, y)$ の2次元フーリエ変換 $F(X, Y)$ は,

$$
F(X, Y)=\int_{-\infty}^{+\infty} \int_{-\infty}^{+\infty} f(x, y) e^{-i(x X+y Y)} d x d y
$$

で表わされ, $X=R \cos \theta, Y=R \sin \theta$ のように極座標表示 し, $r=x \cos \theta+y \sin \theta, d x d y=d r d s$ から,

$$
\begin{aligned}
& F(R \cos \theta, R \sin \theta)=\int_{-\infty}^{+\infty} \int_{-\infty}^{+\infty} f(x, y) e^{-i R r} d r d s \\
& \quad=\int_{-\infty}^{+\infty}\left[\int_{-\infty}^{+\infty} f(x, y) d s\right] e^{-i R r} d r=\int_{-\infty}^{+\infty} p(r, \theta) e^{-i R r} d r
\end{aligned}
$$

と表すことができる。すなわち, $p(r, \theta)$ を得ることによ り, $f(x, y)$ のフーリエ変換 $F(X, Y)$ は, 完全に定まり, 減 衰係数の分布 $f(x, y)$ は, $F(X, Y)$ の2次元フーリ工変換で ある以下の式

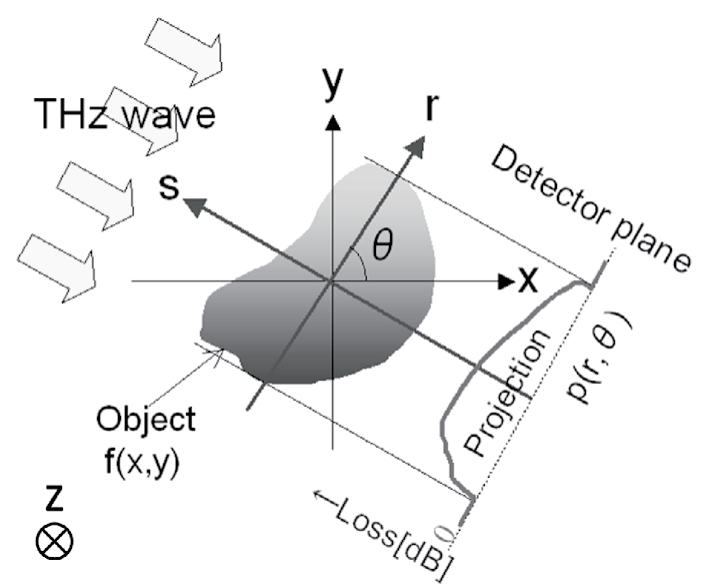

Fig. 7 Projection data $p(r, \theta)$.

$$
f(x, y)=\frac{1}{(2 \pi)^{2}} \int_{-\infty}^{+\infty} \int_{-\infty}^{+\infty} F(X, Y) e^{-2 \pi i(x X+y Y)} d X d Y
$$

により求められる.

全ての $r, \theta$ についての $f(x, y)$ のラドン変換值である投 影デー夕は，サイノグラムと呼ばれ，サイノグラムに逆 投影演算を施すことで元の減衰係数の分布 $f(x, y)$ である 断層像の再構成が可能である.

実際の測定デー夕の取得においては， $x, y$ 軸に対して 垂直な軸をるとして，ある $z$ 位置で被測定物を $r ， \theta$ 方向に 空間的に走査することで一つの $f(x, y)$ 断面が測定され る。また, さらに別の $z$ 位置においても空間走査を行い, それらの断面を重ねることで3D断層像が得られる。

\section{3. $\mathrm{THz}$ CT(TAS7000)の測定例}

\section{1 疑似試薬サンプル}

測定サンプルには，試薬として糖のラクトースとアミ ノ酸のチロシンとをそれぞれポリエチレン粉末で重量比 $5 \%$ に希釈したものを使用した。それらを ン円筒の $\phi 8, \phi 10$ の穴を開けた部分に，それぞれ詰め込 んだ(Fig. 8 (a)).

Fig. 8 (b)に，使用した試薬ラクトースとチロシンの サンプル単体の分光透過スペクトルを示す。 ラクトース は0.53 THz，チロシンは0.96 THzに急峻な吸収スペクト ルを持っていることが分かる。これらは，指紋スペクト ルと呼ばれる物質固有のスペクトル ${ }^{1)}$ とられ，成分の 同定に利用することができる。

$\mathrm{THz}$ CTは, サイノグラムを求める周波数帯域を変え ることで，断層像の各画素にスペクトル由来の情報を持 たせることができるので，以下の様に，被測定物の成分 を分離した解析が可能である。

Fig. 9 (a) と（b) はそれぞれ，チロシン吸収周波数 $0.96 \mathrm{THz}$ で取得したサイノグラムとその再構成断面像で あり，Fig. 9 (c) と（d）はそれぞれ，ラクトースの吸収周 波数 $0.53 \mathrm{THz}$ で取得したサイノグラムと再構成断面像で ある。ラクトースとチロシンが区別して検出されてい る.

さらにFig. 10に各2D断面を積み重ねて構成した3D立 体画像を示す。（a）は，特定の吸収周波数を使用せず全 帯域の積分画像であり，その構造を観察することができ
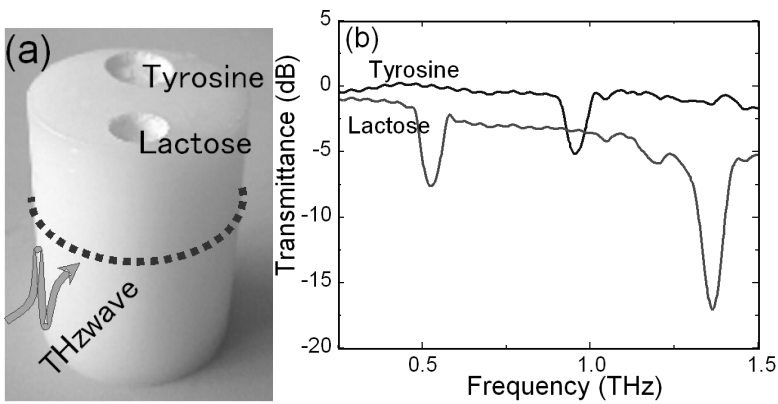

Fig. 8 Analysis of powders: (a) Photograph of test sample (b) Transmission spectra of tyrosine and lactose. ${ }^{8)}$ 
ている.（b)は，各々の吸収周波数の像を重ねたもので あり，成分が分離して表示されている。

\subsection{DPF内に堆積するPM分布の解析}

次に, 実用的な解析例として, ディーゼル・エンジン 用セラミックフィルタの非破壊イメージング解析につい て紹介する。

ディーゼル・エンジンの排気ガスには，健康に対して 有害な粒子状物質 (Particulate Matter, 以下PMと略記)が 含まれており，近年PMに対する規制強化が進んでい $る^{21)}$ 。排気ガスの浄化に用いられる主要部品は, Diesel engine Particulate Filter (DPF) と呼ばれ，両端が交互に塞 がれた多孔質八ニカムセラミックス構造となっている (Fig. 11（a)）。DPFに排ガスを通すことで，側壁がフィ ルタとして作用し, 排気ガス中の $99 \%$ 以上のPMを捕集 でき ${ }^{22}$ 排出ガスは浄化される。 但し, 走行距離に応じて
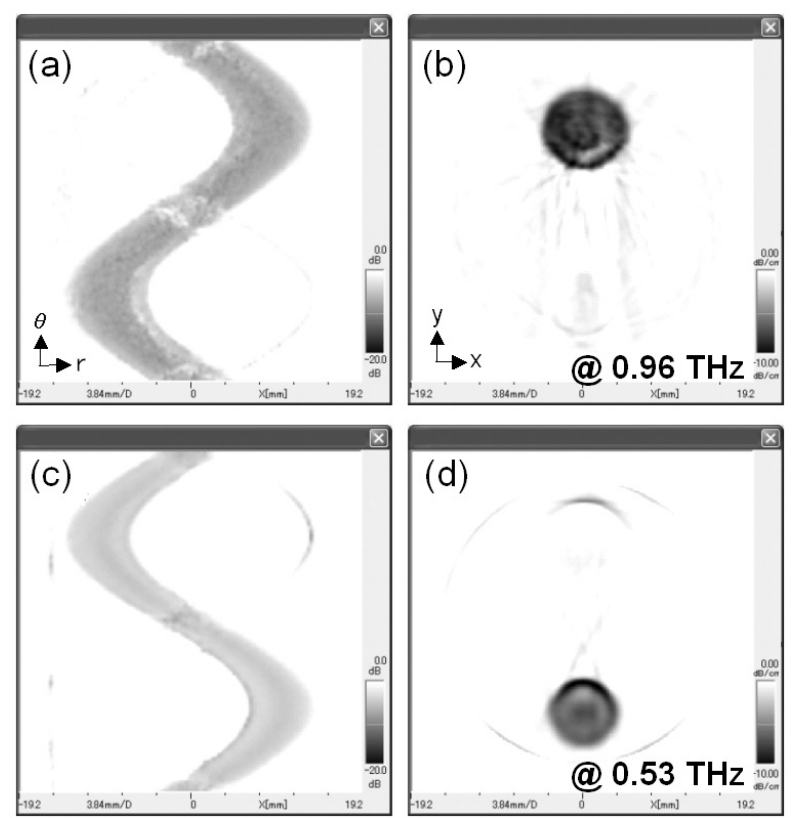

Fig. 9 Sinogram and reconstructed cross sections of test sample: (a) Sinogram for $0.96 \mathrm{THz}$ (tyrosine), (b) Reconstructed cross section calculated from (a), (c) Sinogram for $0.53 \mathrm{THz}$ (lactose) and (d) Reconstructed cross section calculated from (c). ${ }^{8}$
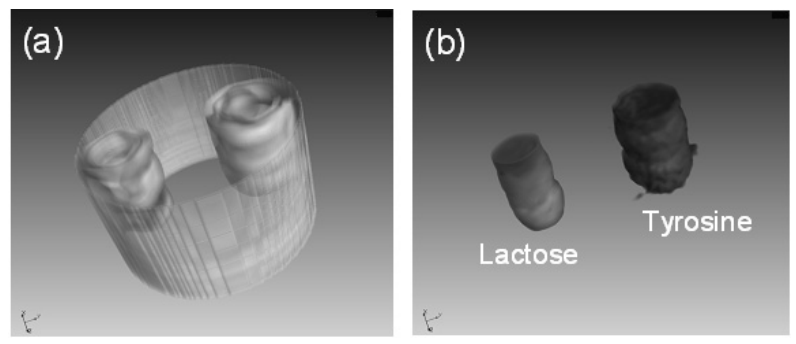

Fig. 10 Reconstructed 3D spectroscopic images of test sample: (a) 3D image for integrated transmission data over the whole spectral range (b) Superimposed 3D images of each powder constituent. ${ }^{8}$
DPF内にPMが堆積されていき，燃費悪化を招くので, 間欠的にエンジンによる強制再生制御を行うことでPM を燃焼除去する仕組みとなっている.

信頼性の高い強制再生を行うには，DPFに堆積する PMの分布状態を把握することが必要であるが，従来は DPFの切断による重量測定が主な解析手法であった。

$\mathrm{THz}$ CTによる解析では, DPF内に堆積するPMの3D濃度 分布を非破壊かつ容易に可視化・解析が可能9)であるた め，不良の要因を効率良く検証することができる。

DPFの解析例として，トラックに搭載され約7万キロ を走行し, 強制再生が繰り返されたと推定されるDPF (Fig. 11 (b))の解析結果を示す.

3Dの解析結果Fig. 12では, DPFの上部から下部方向に 排気ガスが流れてDPF内部に捕集されたPM成分の分布 が可視化されている。 この解析結果から，いくつかの特 徴的な情報が読み取れる。(1)DPF下部に強制再生で燃焼 せずに残ったアッシュ(灰成分)層がある。アッシュは, 通常走行距離に応じて徐々に溜まり, 出力低下や燃費悪 化を招く，(2)強制再生時に受けたDPFの熱的変性による ものと考えられるPM濃度ムラが上下方向に伸びてい る、X線による非破壊検査では，軽元素である炭素の吸 収率が非常に低いため炭素を主成分とするPMではほと んどコントラストが得られない2 ${ }^{23}$ が，THz波による解析

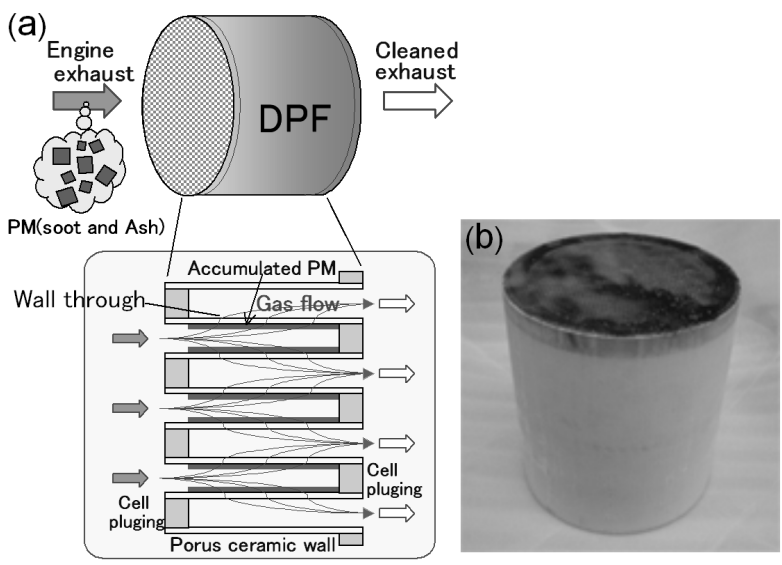

Fig. 11 Analysis sample: (a) Structure of DPF (b) Photo of DPF (70,000 km Run, $\phi 190 \times$ H203).

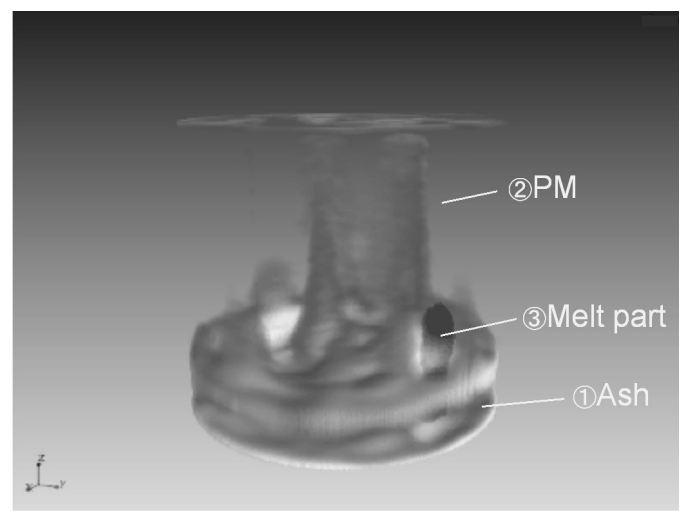

Fig. 12 3D image of sample DPF. ${ }^{20)}$ 


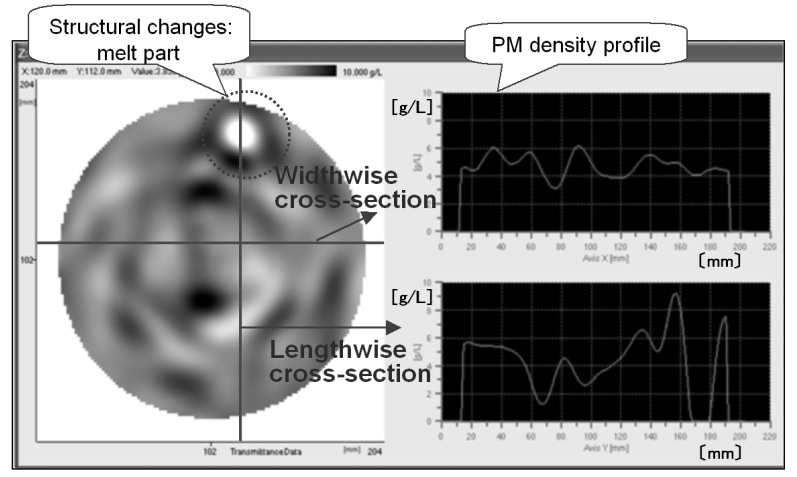

Fig. 13 2D visualization of PM analysis 2D visualization of PM analysis. ${ }^{20)}$

では，明瞭な分布形状で，濃度分布が解析されている。 (3)特異的にPM濃度が低い部分が存在している。これは, Fig. 13の2DイメージからDPF基材の一部が熱によって溶 けた溶損部と推定され，DPF内部の構造的不良を確認す ることができている。

\section{4. むすび}

THz CTは，従来のX線CT装置には無かったスペクト ル情報を基に3Dで可視化する新しい技術に基づいてい る。本稿では，糖とアミノ酸の吸収スペクトル情報を CT測定することで，それらを識別した分布測定が行え ることを例にその有効性の一端を示した，また，既に活 用されている実用的な解析例として, ディーゼル・エン ジン用セラミックフィルタ内のPM分布解析を示した。

THz波によるイメージングは, 医薬品の結晶形などの 製剂分析 ${ }^{24)}$ やバイオ関連 ${ }^{25)}$ な゙への応用も期待され, 我々は, これらのアプリケーションに対しても, $\mathrm{THz}$ Time of Flight方式によるイメージングの要素技術を開発 し, 既にTAS7500 THz分光イメージング・システムとし て製品化を果たしているや。今後, THz技術の発展と共 に，THz波イメージングが様々な分野で活躍することを 願っている。

\section{謝 辞}

本装置のTHz CT技術については, 名古屋大学川瀬 晃道教授より御指導頂きました。この場を借りて深く感
謝申し上げます

\section{参考文献}

1) K. Kawase, Y. Ogawa, Y. Watanabe, and H. Inoue: Opt. Express 11 (2003) 2549

2) A. Dobroiu, C. Otani, and K. Kawase: Meas. Sci. Technol. 17 (2006) 161.

3) J. Radon: Berichte Saechsiche Akademie der Wissenschaften 69 (1917) 262.

4) A. C. Kak and M. Slaney: Principles of computerized tomographic imaging (IEEE Press, New York, 1988).

5) E. C. Beckmann: British J. Radiology 79 (2006) 5.

6) K. L. Nguyen, M. L. Johns, and L. F. Gladden: Opt. Express 14 (2006) 2123.

7) B. S. Ferguson, S. Wang, D. Gray, D. Abbot, and Xi. Zhang: Opt. Lett. 27 (2002) 1312.

8) M. Imamura, S. Nishina, A. Irisawa, T. Yamashita, and E. Kato: Infrared Millimeter and Terahertz Waves (IRMMW-THz), 2010 35th Int. Conf., p.1-3.

9) S. Nishina, K. Takeuchi, M. Shinohara, M. Imamura, M. Shibata, Y. Hashimoto, and F. Watanabe: SAE Paper 2011-01-2064 (JSAE 20119333), 2011 PF\&L Conf. (Kyoto).

10) D. H. Auston, K. P. Cheung, J. A. Valdmanis, and D. A. Kleinman: Phys. Rev. Lett. 53 (1984) 1555

11) Ch. Fattinger and D. Grischkowsky: Appl. Phys. Lett. 53 (1988) 1480 .

12) P. A. Elzinga, R. J. Kneisler, F. E. Lytle, Y. Jiang, G. B. King, and N. M. Laurendeau: Appl. Opt. 26 (1987) 4303.

13) H. Takara, S. Kawanishi, A. Yokoo, S. Tomaru, T. Kitoh, and M. Saruwatari: Electron.Lett. 32 (1996) 2256.

14) C. Janke, M. Forst, M. Nagel, H. Kurz, and A. Bartels: Opt. Lett. 30 (2005) 1405.

15）山下友勇，入澤昭好：日本特許第4782889号（2011）.

16) J. B. Schlager, R. P. Mirin, and N. A. Sanford: IEEE Photon. Technol. Lett. 14 (2002) 1351.

17) E. A. De Souza, C. E. Soccolich, W. Pleibel, R. H. Stolen, J. R. Simpson, and D. J. DiGiovanni: Electron. Lett. 29 (1993) 447.

18) S. Masuda, S. Niki, and M. Nakazawa: Opt. Express 17 (2009) 6613.

19）橋本 雄幸，篠原広行：C言語による画像再構成の基礎，医 療科学社 (2006).

20）橋本昌一，加藤 英志，高柳史一，西名 繁樹，入澤 昭好， 今 村 元 規：MWE2011 (Microwave workshop \& Exhibition), yokohama, 2011, workshop11.

21) 自動車NOx・PM法(自動車から排出される窒素酸化物び粒 子状物質の特定地域総における総量の削減等に関する特別 措置法)，2002.

22) J. Andersson: AECC (Aberdeen Exhibition \& Conference Centre) Technical Seminar, Brussels, 2007.

23) A. Strzelec, H. Bilheux, C. Finney, C. Daw, D. Foster, C. Rutland, B. Schillinger, and M. Schulz: SAE Paper 2009-01-2735.

24) S. Byrn, R. Pfeiffer, M. Ganey, C. Hoiberg, and G. Poochikian: Pharm. Res. 12 (1995) 945.

25) S. Mickan, A. Menikh, H. Liu, C. Mannella, R. MacColl, D. Abbott, J. Munch, and Xi. Zhang: Phys. Med. Biol. 47 (2002) 3789 . 